\section{revista chapingo \\ serie ciencias forestales $\mathrm{v}$ del ambiente}

Revista Chapingo. Serie Ciencias Forestales y del Ambiente

ISSN: 2007-3828

rforest@correo.chapingo.mx

Universidad Autónoma Chapingo

México

Almaraz-Sánchez, Alejandra; Alvarado-Rosales, Dionicio; Tlapal-Bolaños, Bertha; Espinoza-Victoria, David

IDENTIFICACIÓN DE HONGOS ANTAGONISTAS A Phytophthora cinnamomi Rands EN BOSQUES DE ENCINO DE EL ARRAYANAL, COLIMA Y TECOANAPA, GUERRERO

Revista Chapingo. Serie Ciencias Forestales y del Ambiente, vol. 18, núm. 3, septiembre-diciembre, 2012, pp. 341-355

Universidad Autónoma Chapingo

Chapingo, México

Disponible en: http://www.redalyc.org/articulo.oa?id=62926234007

Cómo citar el artículo

- Número completo

- Más información del artículo

Página de la revista en redalyc.org

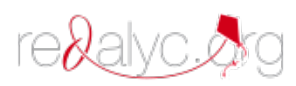

Sistema de Información Científica

Red de Revistas Científicas de América Latina, el Caribe, España y Portugal Proyecto académico sin fines de lucro, desarrollado bajo la iniciativa de acceso abierto 


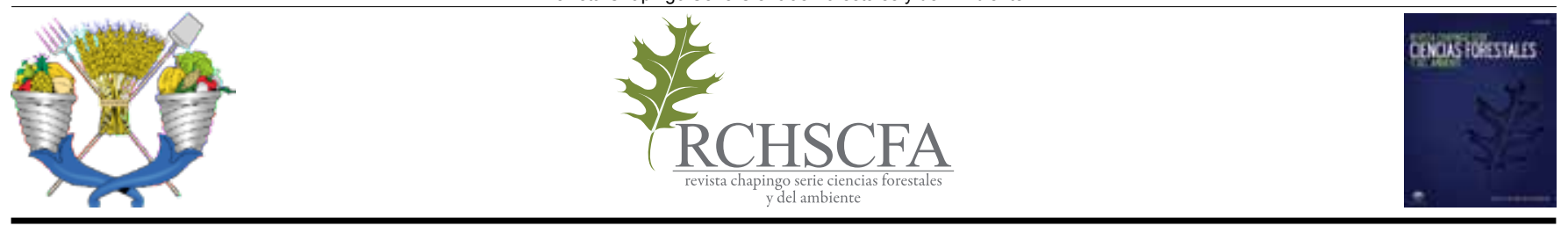

\title{
IDENTIFICACIÓN DE HONGOS ANTAGONISTAS A Phytophthora cinnamomi Rands EN BOSQUES DE ENCINO DE EL ARRAYANAL, COLIMA Y TECOANAPA, GUERRERO
}

\section{IDENTIFICATION OF FUNGI POTENTIALLY ANTAGONIST TO Phytophthora cinnamomi Rands IN OAK FOREST AT THE EL ARRAYANAL, COLIMA AND TECOANAPA, GUERRERO}

\author{
Alejandra Almaraz-Sánchez ; Dionicio Alvarado-Rosales ${ }^{1}$; Bertha Tlapal-Bolaños²; David Espinoza-Victoria ${ }^{3}$ \\ ${ }^{1}$ Programa de Fitopatología, Colegio de Postgraduados. km 36.5, Carretera México-Texcoco. C. P. 56230. Montecillo, Texcoco, Estado de México. \\ Correo-e: alejandraas@colpos.mx ("Autor para correspondencia). \\ ${ }^{2}$ Departamento de Parasitología Agrícola, Universidad Autónoma Chapingo. km 38.5, Carretera México-Texcoco. C. P. 56230. Chapingo, Texcoco, \\ Estado de México. \\ ${ }^{3}$ Programa de Edafología, Colegio de Postgraduados. km 36.5, Carretera México-Texcoco. C. P. 56230. Montecillo, Texcoco, Estado de México.
}

\begin{abstract}
RESUMEN
El objetivo del presente estudio fue identificar morfológica y molecularmente la micoflora que posee propiedades antagonistas sobre Phytophthora cinnamomi, asociada al suelo del bosque de encino (Quercus spp.) de El Arrayanal, Colima, y de Tecoanapa, Guerrero. En estas localidades se realizaron dos muestreos de suelo colectándose muestras compuestas de suelo-raíz alrededor de los árboles con diferentes edades y condiciones sanitarias en rodales afectados por $P$. cinnamomi. Los hongos se identificaron morfológicamente mediante la técnica de dilución de suelo PDA-TS (papa-dextrosaagar-tergitol-estreptomicina). Con los aislamientos obtenidos se realizaron pruebas de antagonismo in vitro. Los aislamientos de Trichoderma, Cordyceps bassiana y Paecilomyces son los que ejercieron mejor biocontrol al reducir el desarrollo de $P$. cinnamomi mostrando mecanismos sobresalientes de competencia por espacio y micoparasitismo. Los hongos se caracterizaron molecularmente amplificando la región intergénica (ITS) de los genes ribosomales mediante la técnica de amplificación por reacción en cadena de la polimerasa (PCR). Se reportan por vez primera a C. bassiana, Cladosporium tenuissimun y seis especies de Trichoderma asociadas al bosque de encino en México.
\end{abstract}

Recibido: 05 de septiembre de 2011 Aceptado: 14 de julio de 2012 doi:10.5154/r.rchscfa.2011.09.061 http://www.chapingo.mx/revistas

\begin{abstract}
The aim of this study was to identify morphologically and molecularly the mycoflora that possesses antagonistic properties on Phytophthora cinnamomi associated to the oak (Quercus spp.) soil forest at El Arrayanal, Colima, and Tecoanapa, Guerrero. Two soil samplings were done in these sites. Soil -root samples around trees with different ages and health conditions in stands affected by P. cinnamo$\mathrm{mi}$ were collected. The fungi were morphologically identified by soil dilution PDA-TS (potato-dextroseagar-tergitol-streptomycin) technique. With the obtained isolates, in vitro antagonism tests were done. Trichoderma spp, Cordyceps bassiana and Paecilomyces isolates, showed the best biological control by reducing $P$. cinnamomi development and showing outstanding mechanisms of space competition and mycoparasitism. The fungi were molecularly characterized by amplifying the intergenic region (ITS) of the ribosomal genes by the amplification of polymerase chain reaction (PCR) technique. For the first time $C$. bassiana, Cladosporium tenuissimun and six Trichoderma species associated with oak forests in Mexico are reported.
\end{abstract}

KEYWORDS:

ITS- rDNA, soil, antagonism, Quercus

\section{INTRODUCCIÓN}

El suelo es el medio donde se desarrolla la vida de innumerables formas de organismos que tienen una gran variedad de actividades, y que contribuyen a incrementar la capacidad productiva del mismo. En un solo gramo de tierra podemos encontrar millones de microorganismos benéficos; bacterias, actinomicetos, hongos, algas y protozoarios (Alexander, 1980).

\section{INTRODUCTION}

Soil is the environment in which life of myriad forms of organisms develops with a wide variety of activities and that contribute to increase soil productivity capacity. In one gram of soil it is possible to find millions of beneficial microorganisms such as bacteria, actinomycetes, fungi, algae and protozoa (Alexander, 1980). 
La actividad de los hongos en el suelo de los bosques es importante para el funcionamiento de los ciclos biogeoquímicos, particularmente en el ciclo del carbono. El ambiente del suelo contiene factores biológicos, químicos y físicos que ejercen efecto sobre la micoflora (Burges \& Raw, 1971). Los hongos son microorganismos activos en el desarrollo de la estructura del suelo; comúnmente el número de hongos por gramo de suelo se ha cuantificado en 8,000 a más de un millón; esto probablemente puede ser equivalente a 1,000 o $1,500 \mathrm{~kg} \cdot \mathrm{ha}^{-1}$, a $20 \mathrm{~cm}$ de profundidad. Aunque la cantidad de bacterias en el suelo es más alta, los hongos son de tamaño superior y presentan una masa mayor de desarrollo por unidad de volumen de suelo (Campbell, Johnson, Philpot, \& Warnock, 1996).

Por otra parte, existen grupos importantes de antagonistas que pueden ser aprovechados en el control biológico y que crecen de manera natural en la rizósfera; entre ellos se encuentran las micorrizas, hongos, bacterias y actinomicetos (Álvarez \& Ferrera-Cerrato, 1994; Papavizas, 1985). La "enfermedad de la tinta"; ocasionada por Phytophthora cinnamomi Rands, está propiciando el incremento de hectáreas afectadas en áreas boscosas de encino en México (Alvarado-Rosales et al., 2007; Alvarado-Rosales, Saavedra-Romero, \& Almaraz-Sánchez, 2008). Sin embargo, el control de la enfermedad no puede ser realizado a través de productos químicos debido al costo que implican y al tipo de cultivo, por lo que una opción es el uso de biocontroladores nativos. Por tal motivo, el objetivo del presente estudio fue identificar morfológica y molecularmente la micoflora que posee propiedades antagonistas sobre $P$. cinnamomi, asociada al suelo del bosque de encino (Quercus spp.) de El Arrayanal, Colima, y de Tecoanapa, Guerrero.

\section{MATERIALES Y MÉTODOS}

\section{Descripción de las áreas de estudio}

El Arrayanal se encuentra ubicado en el municipio de Minatitlán, en la porción noroeste del estado de Colima, a una distancia aproximada de $20 \mathrm{~km}$ en línea recta del sur de Minatitlán y a $45 \mathrm{~km}$ al oeste de la ciudad de Colima. El clima se clasifica como A (w0) y BS1 ( $h^{\prime}$ ), cálido subhúmedo con lluvias en verano, de menor humedad y semiseco muy cálido. El suelo es de tipo Regosol eútrico y dístrico, aunque en pequeñas superficies se pueden presentar Cambisoles crómicos y dístricos (Moreno et al., 2001).

El municipio de Tecoanapa tiene una extensión territorial de $776.9 \mathrm{~km}^{2}$ y se ubica en la Costa Chica del estado de Guerrero. El clima es w2, que corresponde a cálido subhúmedo con lluvias en verano (junio a octubre) con una precipitación de 1,300 a 1,500 mm anuales. El municipio se ubica en terrenos con pendientes fuertes a moderadas, con geología de rocas sedimentarias (calizas), predominando los suelos arenosos, delgados y pe-
Fungi activity in the forest soil is important for the biogeochemical cycles functioning, particularly the carbon cycle. The soil environment contains biological, chemical and physical factors that affect mycoflora (Burges \& Raw, 1971). Fungi are active microorganisms in the soil structure development; usually the number of fungi per gram of soil was measured on 8,000 to over a million; this can probably be equivalent to 1,000 or 1,500 $\mathrm{kg} \cdot \mathrm{ha}^{-1}$, at $20 \mathrm{~cm}$ deep. Although the bacteria amount in the soil is higher, fungi are oversized and have a higher mass development per unit volume of soil (Campbell, Johnson, Philpot, \& Warnock, 1996).

On the other hand, there are important antagonists groups that can be exploited in biological control and that naturally grow in the rhizosphere; among them are mycorrhizae, fungi, bacteria and actinomycetes (Álvarez \& Ferrera-Cerrato, 1994; Papavizas, 1985). The «ink disease» caused by Phytophthora cinnamomi Rands, is driving the increase of affected oak forest areas in Mexico (Alvarado-Rosales et al., 2007; Alvarado-Rosales, Saavedra-Romero, Almaraz-Sánchez, 2008). However, disease control cannot be performed through chemicals because of the cost involved and the crop type, thus, one option is the use of native biocontrol agents. Therefore, the aim of this work was to identify morphologically and molecularly the mycoflora that possesses antagonistic properties on P. cinnamomi, associated to El Arrayanal, (Colima) and Tecoanapa (Guerrero) oak forest soils (Quercus spp).

\section{MATERIALS AND METHODS}

\section{Study areas description}

El Arrayanal is located in the town of Minatitlannorthwestern portion of Colima state, approximately 20 $\mathrm{km}$ directly south of Minatitlan and $45 \mathrm{~km}$ west of Colima city. The climate is classified as A (w0) and BS1 (h'), warm subhumid with summer rains, low humidity and very warm semidry. The soil type is Eutric Regosol and Dystric, although in small areas it can be observed chromic cambisols and Dystrics (Moreno et al., 2001).

Tecoanapa municipality has a territory of 776.9 $\mathrm{km}^{2}$ and is located in the Costa Chica of Guerrero state. The climate is w2, which corresponds to warm subhumid with summer rains (June to October) with a total annual rainfall of 1,300 to $1,500 \mathrm{~mm}$. The municipality is located on land with steep to moderate slopes, with geology of sedimentary rocks (limestone), predominantly sandy soils, thin and stony (Lithosols, Rendzinas and Regosols) (Xalpatláhuac Territorial Reorganization Study, 2004; Estudio de Reordenamiento Territorial de Xalpatláhuac, 2004). 
dregosos (Litosoles, Rendzinas y Regosoles) (Estudio de Reordenamiento Territorial de Xalpatláhuac, 2004).

\section{Fase de campo}

En cada localidad se seleccionaron sitios de muestreo de 0.1 ha para determinar la micoflora del suelo. En cada sitio se tomaron cinco muestras compuestas (sueloraíz) de $1 \mathrm{~kg}$, correspondientes a cinco árboles; uno ubicado en el centro y el resto en los cuatro puntos cardinales. Las muestras se colectaron a una profundidad de 10 $\mathrm{cm}$ de la rizósfera del árbol. En El Arrayanal se muestrearon once sitios en julio de 2005 y en febrero de 2008. En cada sitio se seleccionaron cinco árboles con diferentes edades y síntomas de la enfermedad, dando un total de 110 árboles e igual número de muestras compuestas. En Tecoanapa, la toma de muestras fue similar; 13 sitios se muestrearon en octubre de 2007 y 12 en enero de 2008, dando un total de 125 muestras y el mismo número de árboles muestreados. Las muestras fueron colocadas en bolsas de plástico, etiquetadas y trasladadas en una hielera para su análisis en laboratorio.

\section{Fase de laboratorio}

\section{Determinación de la micoflora de las muestras del rizoplano}

La población de la micoflora presente en el suelo de los sitios se estimó con la técnica de dilución de suelo PDA-TS (Papa-Dextrosa-Agar-Tergitol-Estreptomicina) de Steiner y Watson (1965), usando la dilución 10-3.

\section{Pruebas de antagonismo in vitro}

Se realizaron bioensayos contra $P$. cinnamomi utilizando los aislamientos obtenidos (Cuadro 1) de los géneros Trichoderma, Gliocladium, Paecilomyces y Cladosporium. La evaluación se hizo mediante la observación de los mecanismos de competencia, micoparasitismo y antibiosis. Para ello, en cajas Petri con medio de cultivo PDA se sembraron discos (5 $\mathrm{mm}$ de diámetro) de micelio activo del patógeno de siete días de edad. Los discos se colocaron en el centro de la caja y se in-

\section{Field Phase}

On each location, 0.1 ha sampling sites were selected to determine soil mycoflora. Five composite samples (soil - root) of $1 \mathrm{~kg}$ were collected on each site. These samples corresponded to five trees, one located in the center and the rest in the four cardinal points. Samples were collected at $10 \mathrm{~cm}$ depth of the tree rhizosphere. Eleven sites were sampled in July 2005 and February 2008 at El Arrayanal. On each site, five trees of different ages and disease symptoms were selected, with a total of 110 trees and an equal number of composite samples. In Tecoanapa the sampling was similar: 13 sites were sampled in October 2007 and 12 sites in January 2008, with a total of 125 samples and the same number of sampled trees. The samples were kept in plastic bags, labeled and transported in a cooler for laboratory analysis.

\section{Laboratory phase}

\section{Mycoflora determination in the rhizoplane samples}

The mycoflora population in soil of the sites was estimated using the PDA-TS (potato-dextrose-agar-Tergitol-Streptomycin) soil dilution technique by Steiner and Watson (1965), using the $10^{-3}$ dilution.

\section{In vitro Antagonism tests}

Bioassays against $P$. cinnamomi were done by using the isolates obtained (Table 1) from Trichoderma, Gliocladium, Paecilomyces and Cladosporium genera. The evaluation was done by observing the mycoparasitism and antibiosis competition mechanisms. Disks $(5 \mathrm{~mm}$ diameter) with seven days old active pathogen mycelium were plated in Petri dishes with PDA culture media. The discs were placed in the center of the box and incubated during $24 \mathrm{~h}$ at room temperature $\left(25^{\circ} \mathrm{C}\right)$ until they reached $1 \mathrm{~cm}$ diameter growth and then three discs of the same size with the antagonistic fungus around the colony were placed. The same procedure, with five replicates, was performed for each of the antagonists and was kept under observation (every 24 hours) during seven days.

CUADRO 1. Aislamientos nativos de El Arrayanal, Colima, y Tecoanapa, Guerrero, utilizados en los bioensayos de antagonismo contra Phytophthora cinnamomi.

\begin{tabular}{|c|c|c|c|c|c|}
\hline Localidad & Hongos & Clave & Localidad & Hongos & Clave \\
\hline \multirow{7}{*}{ El Arrayanal } & Trichoderma & $\mathrm{TC}-1$ & & Trichoderma & TG-1 \\
\hline & Trichoderma & TC-2 & & Trichoderma & TG-3 \\
\hline & Trichoderma & TC-4 & & Trichoderma & TG-4 \\
\hline & Trichoderma & TC-6 & Tecoanapa & Trichoderma & TG-6 \\
\hline & Paecilomyces & $\mathrm{PC}$ & & Cladosporium & CG \\
\hline & Cladosporium & $\mathrm{CC}$ & & Paecilomyces & $P G$ \\
\hline & Gliocladium & $\mathrm{GC}$ & & & \\
\hline
\end{tabular}


TABLE 1. Native isolates from El Arrayanal (Colima) and Tecoanapa (Guerrero) used in the antagonism bioassays against Phytophthora cinnamomi.

\begin{tabular}{cccccc}
\hline Location & Fungi & Key & Location & Fungi & Key \\
\hline & Trichoderma & TC-1 & & Trichoderma & TG-1 \\
& Trichoderma & TC-2 & & Trichoderma & TG-3 \\
& Trichoderma & TC-4 & & Trichoderma & TG-6 \\
El Arrayanal & Trichoderma & TC-6 & Tecoanapa & Cladosporium & CG \\
& Paecilomyces & PC & & Paecilomyces & PG \\
& Cladosporium & CC & & & \\
\hline
\end{tabular}

cubaron por $24 \mathrm{~h}$ a temperatura ambiente $\left(25^{\circ} \mathrm{C}\right)$ hasta alcanzar $1 \mathrm{~cm}$ de diámetro de crecimiento. Alcanzado dicho diámetro, se colocaron tres discos del mismo tamaño del hongo antagonista alrededor de la colonia. El mismo procedimiento, con cinco repeticiones, se realizó para cada uno de los antagonistas y se mantuvieron bajo observación (cada 24 h) durante siete días.

\section{Identificación morfológica y molecular de las especies antagónicas}

Los aislamientos se cultivaron en PDA e incubaron a $24{ }^{\circ} \mathrm{C}$ con luz blanca constante por cinco días. De cada aislamiento se midieron 100 esporas y se observó el tipo de micelio, fiálide y presencia o ausencia de clamidosporas. La caracterización morfológica de Trichoderma se hizo con ayuda de las claves de Kubicek y Harman (1998). Los Hyphomycetes Gliocladium y Paecelomyces se identificaron con las claves de Domsch, Gams, y Anderson (1980). El hongo Cladosporium fue identificado con las claves de Barnett y Hunter (1998). La especie de Phytophthora se identificó con las claves de Waterhouse (1963) y Erwin y Ribeiro (1996).

La identificación molecular de los aislamientos purificados se hizo mediante la extracción de ADN con la técnica de Ahrens y Seemuller (1992). La calidad del ADN se verificó por electroforesis en gel de agarosa al $0.8 \%$ y se cuantificó en un espectrofotómetro Perkin Elmer (modelo Lambda Bio10). Con la técnica de PCR (Polymerase Chain Reaction) se amplificaron las regiones ITS (Internal Transcribed Spacer) utilizando los iniciadores ITS5 (GGAAGTAAAAGTCGTAACAAGG) e ITS4 (TCCTCCGCTTATTGATATGC), de los genes ARNr (ácido ribonucleico ribosomal), subunidades 18S$5.8 S$ y $5.8 S-28 S$ (White, Bruns, Lee, \& Taylor, 1990). En cada mezcla de PCR se utilizó un volumen final de $25 \mu \mathrm{L}$ con la siguiente formulación: $13.22 \mu \mathrm{L}$ de agua ultrapura estéril, $2.5 \mu \mathrm{L}$ de solución amortiguadora (TBE 1X), 2.08 $\mu \mathrm{L}$ de $\mathrm{MgCl}_{2}(2.5 \mathrm{mM}), 2 \mu \mathrm{L}$ de dNTPs $(2.0 \mathrm{mM}), 2 \mu \mathrm{L}$ de cada uno de los iniciadores ITS5 e ITS4 (20 pmol), $0.2 \mu \mathrm{L}$ de Taq DNA polimerasa $(1.5 \mathrm{U})$ y $1 \mu \mathrm{L}$ de ADN (80 ng). La reacción se llevó a cabo en un termociclador Perkin-Elmer (modelo CT 2400) con el siguiente progra-

\section{Morphological and molecular identification of antagonistic species}

The isolates were cultivated on PDA culture media and incubated at $24{ }^{\circ} \mathrm{C}$ with constant white light during five days. From each isolated fraction, 100 spores were measured and observed for mycelium type, phialides and chlamydospores presence or absence. The Trichoderma morphological characterization was done using Kubicek and Harman (1998) keys. The Hyphomycetes Paecelomyces and Gliocladium were identified with Domsch, Gams \& Anderson (1980) keys. Cladosporium fungus was identified with Barnett and Hunter (1998) keys. Phytophthora species was identified with Waterhouse (1963) and Erwin and Ribeiro (1996) keys.

The molecular identification of purified isolates was done by extracting DNA with Ahrens and Seemuller (1992) technique. DNA quality was verified by $0.8 \%$ agarose gel electrophoresis and was quantified on a Perkin Elmer spectrophotometer (Model Lambda Bio10). Using the PCR technique (Polymerase Chain Reaction), the ITS (Internal Transcribed Spacer) regions were amplified using the ITS5 (GGAAGTAAAAGTCGTAACAAGG) and ITS4 (TCCTCCGCTTATTGATATGC) primers from the rRNA (ribosomal ribonucleic acid) genes, 18S- 5.8S and 5.8S- $28 S$ subunits (White, Bruns, Lee, \& Taylor, 1990). On each PCR mixture, a final volume of $25 \mu \mathrm{L}$ was used with the following formulation: $13.22 \mu \mathrm{L}$ of sterile ultrapure water, $2.5 \mu \mathrm{L}$ of buffer (1X TBE), $2.08 \mu \mathrm{L}$ of $\mathrm{MgCl}_{2}(2.5 \mathrm{mM}), 2 \mu \mathrm{L}$ of dNTPs $(2.0 \mathrm{mM}), 2 \mu \mathrm{L}$ of each ITS5 and ITS 4 primers ( $20 \mathrm{pmol}), 0.2 \mu \mathrm{L}$ of Taq DNA polymerase $(1.5 \mathrm{U})$ and $1 \mu \mathrm{l}$ of DNA ( $80 \mathrm{ng})$. The reaction was conducted in a Perkin-Elmer thermocycler (model CT 2400) with the following program: initial denaturation at $95{ }^{\circ} \mathrm{C}$ during $2 \mathrm{~min} ; 30$ denaturation cycles at $95^{\circ} \mathrm{C}$ during $1 \mathrm{~min}$; alignment at $50^{\circ} \mathrm{C}$ during $30 \mathrm{~s}$; extension at $72{ }^{\circ} \mathrm{C}$ during $2 \mathrm{~min}$, and final extension at $72{ }^{\circ} \mathrm{C}$ during $10 \mathrm{~min}$. The amplified fragment was purified using the Qiagen ${ }^{\circledR}$ KIT. The fragment quality was verified in $1 \%$ agarose gel electrophoresis and it was stained with ethidium bromide. The produced band was visualized in a transilluminator (Gel Doc 2000, BIO-RAD ${ }^{\circledR}$ ). The $P C R$ product was sent for sequencing at Macrogen 
ma: desnaturalización inicial a $95^{\circ} \mathrm{C}$ por 2 min; 30 ciclos de desnaturalización a $95{ }^{\circ} \mathrm{C}$ por $1 \mathrm{~min}$, alineación a 50 ${ }^{\circ} \mathrm{C}$ por $30 \mathrm{~s}$, extensión a $72{ }^{\circ} \mathrm{C}$ por 2 min; y extensión final a $72{ }^{\circ} \mathrm{C}$ por $10 \mathrm{~min}$. El fragmento amplificado se purificó con el KIT Quiagen ${ }^{\circledR}$. La calidad del fragmento se verificó por medio de electroforesis en gel de agarosa al $1 \%$ y se tiñó con bromuro de etidio. La banda producida se visualizó en un transiluminador (Gel Doc 2000, BIO-RAD ${ }^{\circledR}$ ). El producto de PCR se envió al laboratorio de Macrogen en Estados Unidos para su secuenciación (Automatic Sequencer 3700xI DNA Analyzer, Macroge), en dos direcciones $\left(5^{\prime} \rightarrow 3^{\prime}\right.$ y $\left.3^{\prime} \rightarrow 5^{\prime}\right)$ con los iniciadores ITS5 e ITS4. Las secuencias de estudio se depositaron en el Banco de Genes del Nacional Center for Biotechnology Information (NCBI) (http://www.ncbi.nlm.nih.gov) y se compararon de manera individual con las secuencias allí disponibles. De los valores cuantitativos generados, sólo se bajaron las secuencias con valor alto para su comparación con las secuencias de estudio. Las secuencias fueron alineadas con ClustalW versión 1.6.

\section{Aislamiento y caracterización molecular de $P$. cinnamomi}

$P$. cinnamomi fue aislado del suelo de los árboles de bosques de encino en El Arrayanal y Tecoanapa. Los árboles presentaban síntomas ocasionados por el patógeno, como marchitez, muerte regresiva, clorosis, defoliación prematura y presencia de cancros con exudado y tinción de la corteza. Los aislamientos se cultivaron en medio de cultivo selectivo PARPH (pimaricina, ampicilina, rifampicina, PCNB [pentacloronitrobenceno], himexazol). Posteriormente, se cultivaron en PDA e incubaron a $25{ }^{\circ} \mathrm{C}$ en oscuridad constante por seis días. De cada aislamiento se midieron 100 esporangios, los cuales se identificaron con las claves de Waterhouse (1963) y Erwin y Ribeiro (1996). La caracterización molecular se realizó con el método de Ahrens y Seemuller (1992).

\section{RESULTADOS Y DISCUSIÓN}

\section{Hongos aislados de los suelos de El Arrayanal, Colima, y Tecoanapa, Guerrero}

En el Cuadro 2 se presentan los aislamientos obtenidos en los sitios de estudio. En El Arrayanal se cuantificaron 5,525 aislamientos agrupados en 10 géneros en las dos épocas de muestreo (julio 2005 y febrero 2008). En Tecoanapa se obtuvieron 6,800 aislamientos y se identificaron ocho géneros en los dos periodos de muestreo (octubre 2007 y enero 2008).

En el primer muestreo de El Arrayanal, el número de aislamientos más frecuentes correspondió al género PeniciIlium, obteniendo $71.46 \%$ respecto del total. En menor porcentaje se identificaron los géneros Aspergillus (12.95\%), Cunningamella (0.79\%), Fusarium (0.36\%), Gliocladium lab in the U.S. (Automatic Sequencer 3700xl DNA Analyzer, Macroge) in two directions $\left(5^{\prime} \rightarrow 3^{\prime}\right.$ and $\left.3^{\prime} \rightarrow 5^{\prime}\right)$ with ITS4 and ITS5primers. Study sequences were deposited in the Gene Bank of the National Center for Biotechnology Information (NCBI) (http://www.ncbi.nlm. nih.gov) and were compared individually with sequences available there. From the quantitative values generated, only sequences with high value were downloaded for comparison with the sequences of study. Sequences were aligned with ClustalW software version 1.6.

\section{$P$. cinnamomi isolation and molecular characterization}

$P$. cinnamomi was isolated from trees soil of the oak forests at El Arrayanal and Tecoanapa. The trees were showing symptoms caused by the pathogen, such as wilting, dieback, chlorosis, premature defoliation and presence of dark bleeding cankers. The isolates were grown in selected culture media PARPH (pimaricin, ampicillin, rifampicin, PCNB [pentachloronitrobenzene], hymexazol). Then they were cultivated on PDA and incubated at $25^{\circ} \mathrm{C}$ in constant darkness during six days, after this time, 100 sporangia from each isolate were measured, which were identified with Waterhouse (1963) and Erwin and Ribeiro (1996) keys. Molecular characterization was performed with Ahrens and Seemuller (1992) method.

\section{RESULTS AND DISCUSSION}

\section{Fungi isolated from El Arrayanal (Colima) and Tecoanapa, (Guerrero) soils}

Table 2 presents the isolates obtained in the study areas. At El Arrayanal, 5,525 isolates were quantified grouped in 10 genera in the two sampling periods (July 2005 and February 2008). In Tecoanapa, 6,800 isolates were obtained and eight genera were identified in the two sampling periods (October 2007 and January 2008).

During the first sampling at El Arrayanal, the most frequent isolates corresponded to the genus Penicillium with $71.46 \%$ of the total. At lower percentage Aspergillus (12.95\%), Cunningamella (0.79\%), Fusarium (0.36 $\%$ ), Gliocladium (0.30\%), Mucor (3.16\%), Paecilomyces (5.96 \%), Rhizopus (0.42\%) and Trichoderma (4.60\%) were identified. During the second sampling, the most frequent isolates were also the genus Penicillium (80.01 $\%)$ and in lower percentage Gliocladium $(0.51 \%)$, Aspergillus (4.1\%), Cladosporium (1.54\%), Cunningamella $(0.77 \%)$, Fusarium (3.86 \%), Paecilomyces (2.0\%) and Trichoderma $(7.21 \%)$.

In Tecoanapa, eight genera were identified in the first sampling. Most isolates were Penicillium with 67.91 $\%$. Aspergillus (6.5\%), Cladosporium (0.54\%), Cunningamella (3.8 \%), Fusarium (3.5\%), Mucor (1.1\%), Paecilomyces (3.8\%) and Trichoderma (12.85\%) were obtained at lower percentages. In the second sampling, the 
CUADRO 2. Número de aislamientos (propágulos por gramo de suelo) obtenidos en El Arrayanal, Colima, y Tecoanapa, Guerrero.

\begin{tabular}{|c|c|c|c|c|}
\hline \multirow[b]{2}{*}{ Géneros } & \multicolumn{2}{|c|}{ El Arrayanal } & \multicolumn{2}{|c|}{ Tecoanapa } \\
\hline & julio, 2005 & febrero, 2008 & octubre 2007 & enero 2008 \\
\hline Aspergillus & 213 & 160 & 240 & 210 \\
\hline Cladosporium & - & 60 & 20 & - \\
\hline Cunningamella & 13 & 30 & 140 & 10 \\
\hline Fusarium & 6 & 150 & 130 & 20 \\
\hline Gliocladium & 5 & 20 & - & - \\
\hline Mucor & 52 & - & 40 & 60 \\
\hline Oomycete & 10 & - & 20 & \\
\hline Paecilomyces & 98 & 80 & 140 & 80 \\
\hline Penicillium & 1,039 & 2,970 & 2,430 & 330 \\
\hline Rhizopus & 7 & - & - & - \\
\hline Trichoderma & 75 & 280 & 470 & 320 \\
\hline Zygomycete & 127 & 130 & 30 & 110 \\
\hline Total & 1,645 & 3,880 & 3,660 & 3,140 \\
\hline
\end{tabular}

(0.30\%), Mucor (3.16\%), Paecilomyces (5.96\%), Rhizopus $(0.42 \%)$ y Trichoderma (4.60 \%). En el segundo muestreo, los aislamientos más frecuentes también fueron del género Penicillium (80.01\%) y en menor porcentaje Gliocladium (0.51\%), Aspergillus (4.1\%), Cladosporium (1.54 $\%)$, Cunningamella (0.77 \%), Fusarium (3.86 \%), Paecilomyces (2.0\%) y Trichoderma (7.21\%).

En Tecoanapa se identificaron ocho géneros en el primer muestreo. La mayoría de los aislamientos correspondieron a Penicillium, el cual representó $67.91 \%$. En menor porcentaje se obtuvieron Aspergillus (6.5\%), Cladosporium (0.54\%), Cunningamella (3.8\%), Fusarium (3.5\%), Mucor (1.1\%), Paecilomyces, (3.8\%) y Trichoderma (12.85\%). En el segundo muestreo, los géneros obtenidos fueron los mismos, excepto por la ausencia de Cladosporium y la clase Oomycetes. Los porcentajes variaron, pero el género Penicillium fue dominante con 77.67 $\%$. En menor porcentaje se identificaron Aspergillus (6.7 $\%$ ), Cunningamella (0.32 \%), Fusarium (0.64 \%), Mucor (1.92 \%), Paecilomyces (2.55 \%) y Trichoderma (10.2 \%). genera obtained were the same except for the Cladosporium and Oomycetes absence. The percentages varied, but the genus Penicillium was dominant with $77.67 \%$. In smaller percentage Aspergillus (6.7\%), Cunningamella (0.32 \%), Fusarium (0.64 \%), Mucor (1.92\%), Paecilomyces $(2.55 \%)$ and Trichoderma (10.2 \%) were identified.

Based on the results, it was determined that most genera was found in July in El Arrayanal and in October in Tecoanapa. The dominance of the genus Penicillium in both soils is because it is a soil permanent colonizer and plays an important role in the cleavage of various substrates. Penicillium's behavior as saprophyte allows it to stay always in the ground, compared to the other fungi species that only grow and develop at certain times, especially when the soil has moisture (Agrios, 2001; Cibrián-Tovar, Alvarado, \& García, 2007). The dynamics of the other genera was different in both samplings. These results agree with other literature reports. Sharma (1981), reports that the genera that dominate the forest soils are Penicillium, Trichoderma and Fusar- 
TABLE 2. Number of isolates (propagules per gram of soil) obtained in El Arrayanal (Colima) and Tecoanapa (Guerrero)

\begin{tabular}{|c|c|c|c|c|}
\hline \multirow[b]{2}{*}{ Genera } & \multicolumn{2}{|c|}{ El Arrayanal } & \multicolumn{2}{|c|}{ Tecoanapa } \\
\hline & July, 2005 & February, 2008 & October 2007 & January, 2008 \\
\hline Aspergillus & 213 & 160 & 240 & 210 \\
\hline Cladosporium & - & 60 & 20 & - \\
\hline Cunningamella & 13 & 30 & 140 & 10 \\
\hline Fusarium & 6 & 150 & 130 & 20 \\
\hline Gliocladium & 5 & 20 & - & - \\
\hline Mucor & 52 & - & 40 & 60 \\
\hline Oomycete & 10 & - & 20 & \\
\hline & & & & - \\
\hline Paecilomyces & 98 & 80 & 140 & 80 \\
\hline Penicillium & 1,039 & 2,970 & 2,430 & 330 \\
\hline Rhizopus & 7 & - & - & - \\
\hline Trichoderma & 75 & 280 & 470 & 320 \\
\hline Zygomycete & 127 & 130 & 30 & 110 \\
\hline Total & 1,645 & 3,880 & 3,660 & 3,140 \\
\hline
\end{tabular}

Con base en los resultados se determinó que el mayor número de géneros se encontró en el mes de julio en El arrayanal y en octubre en Tecoanapa. La dominancia del género Penicillium en ambos suelos se debe a que es un colonizador permanente del suelo y desempeña un papel importante en el desdoblamiento de diferentes sustratos. El comportamiento de Penicillium como saprofito le permite permanecer siempre en el suelo, en comparación con las otras especies de hongos que sólo crecen y se desarrollan en ciertas épocas, principalmente cuando el suelo presenta humedad (Agrios, 2001; Cibrián-Tovar, Alvarado, \& García, 2007). La dinámica del resto de los géneros fue diferente en ambos muestreos. Estos resultados concuerdan con lo que se consigna en la literatura. Sharma (1981) reporta que los géneros que predominan en suelos de bosque son Penicillium, Trichoderma y Fusarium. Lumley, Gignac, y Currah (2001) mencionan que las especies más comunes aisladas de suelo en bosque de Populus y Picea pertenecen a los géneros Trichoderma, Penicillium, Mortierella y AspergiIlus. Por su parte, Martínez, Valenzuela y Godoy (2005) ium. Lumley, Gignac, \& Currah (2001) reported that the most common species isolated from soil in Populus and Picea forest belong to the genera Trichoderma, Penicillium, Mortierella and Aspergillus. Meanwhile, Martinez, Valenzuela and Godoy (2005) found that the most abundant fungi in regions of Alberta, Canada, were Penicillium, Mortierella and Trichoderma. In general, Penicillium is present in most Mexico forest soils (Cibrián et al., 2007). Kubatova (1996) reports that this fungus can also be found in declining forests (oak and coniferous forests) and that may be associated with wood-staining fungi (Ophiostoma and Trichoderma).

Moniliaceae family, where Aspergillus, Fusarium and Penicillium belong to, is causing economic losses in stock, natural forests, plantations and nurseries (Cibrián et al., 2007). Oomycetes and Zygomycetes are organisms found in all terrestrial environments, and its parasitism varies from necrotrophic to biotrophic. In the Mucorales order there are some important genera from the forest point of view such as Rhizopus and Mucor. Many of these are 
observaron que los hongos más abundantes en las regiones de Alberta, Canadá, fueron Penicillium, MortiereIla y Trichoderma. En general, Penicillium se encuentra en los suelos forestales de México (Cibrián et al., 2007). Kubatova (1996) menciona que este hongo también se puede encontrar en bosques con declinación (encinares y bosques de coníferas) y que puede estar asociado con hongos manchadores (Ophiostoma y Trichoderma).

La familia Moniliaceae, dentro de la cual se encuentran Aspergillus, Fusarium y Penicillium, es causante de pérdidas económicas en almacén, bosques naturales, saprophytes and grow in manure, soil, humus and other organic wastes (Cibrián et al., 2007). There are reports that the genera Cladosporium, Gliocladium and Paecilomyces, whose populations were low in this study, help to reduce the amount of phytopathogen inoculum that affect the root (Ahmed, Pérez-Sánchez, Egea \& Candela, 1999).

\section{Antagonism in vitro tests}

The mechanisms of action of each fungi tested are reported in Table 3. Based on the antagonism tests, it was observed that all Trichoderma isolates invaded $P$.

CUADRO 3. Aislamientos confrontados con Phytophthora cinnamomi y mecanismos de antagonismo observados.

\begin{tabular}{|c|c|c|c|c|}
\hline Origen & Organismo & Micoparasitismo & Antibiosis & Competencia \\
\hline \multirow[t]{7}{*}{ El Arrayanal } & Trichoderma 1 & $\sqrt{ }$ & & $\sqrt{ }$ \\
\hline & Trichoderma 2 & $\sqrt{ }$ & & $\sqrt{ }$ \\
\hline & Trichoderma 4 & $\sqrt{ }$ & & $\sqrt{ }$ \\
\hline & Trichoderma 6 & $\sqrt{ }$ & & $\sqrt{ }$ \\
\hline & Paecilomyces & $\sqrt{ }$ & & \\
\hline & Cladosporium & $\sqrt{ }$ & & \\
\hline & Gliocladium & & $\sqrt{ }$ & \\
\hline \multirow[t]{6}{*}{ Tecoanapa } & Trichoderma 1 & $\sqrt{ }$ & & $\sqrt{ }$ \\
\hline & Trichoderma 3 & $\sqrt{ }$ & & $\sqrt{ }$ \\
\hline & Trichoderma 4 & $\sqrt{ }$ & & $\sqrt{ }$ \\
\hline & Trichoderma 6 & $\sqrt{ }$ & & $\sqrt{ }$ \\
\hline & Cladosporium & $\sqrt{ }$ & & \\
\hline & Paecilomyces & & $\sqrt{ }$ & \\
\hline
\end{tabular}

TABLE 3. Isolates confronted with Phytophthora cinnamomi and antagonism mechanisms observed.

\begin{tabular}{|c|c|c|c|c|}
\hline Source & Organism & Mycoparasitism & Antibiosis & Competition \\
\hline \multirow[t]{7}{*}{ El Arrayanal } & Trichoderma 1 & $\sqrt{ }$ & & $\sqrt{ }$ \\
\hline & Trichoderma 2 & $\sqrt{ }$ & & $\sqrt{ }$ \\
\hline & Trichoderma 4 & $\sqrt{ }$ & & $\sqrt{ }$ \\
\hline & Trichoderma 6 & $\sqrt{ }$ & & $\sqrt{ }$ \\
\hline & Paecilomyces & $\sqrt{ }$ & & \\
\hline & Cladosporium & $\sqrt{ }$ & & \\
\hline & Gliocladium & & $\sqrt{ }$ & \\
\hline \multirow[t]{6}{*}{ Tecoanapa } & Trichoderma 1 & $\sqrt{ }$ & & $\sqrt{ }$ \\
\hline & Trichoderma 3 & $\sqrt{ }$ & & $\sqrt{ }$ \\
\hline & Trichoderma 4 & $\sqrt{ }$ & & $\sqrt{ }$ \\
\hline & Trichoderma 6 & $\sqrt{ }$ & & $\sqrt{ }$ \\
\hline & Cladosporium & $\sqrt{ }$ & & \\
\hline & Paecilomyces & & $\sqrt{ }$ & \\
\hline
\end{tabular}


plantaciones forestales y viveros (Cibrián et al., 2007). Los Oomycetes y Zygomycetes son organismos que se encuentran en todos los ambientes terrestres, y su parasitismo varía desde necrotróficos a biotróficos. En el orden de los Mucorales se encuentran algunos géneros de importancia desde el punto de vista forestal como Rhizopus y Mucor. Muchos de éstos son saprofitos y crecen en estiércol, suelo, humus y otros desechos orgánicos (Cibrián et al., 2007). Existen reportes que indican que los géneros Cladosporium, Gliocladium y Paecilomyces, cuyas poblaciones fueron bajas en este estudio, contribuyen a disminuir la cantidad de inóculo de fitopatógenos que afectan la raíz (Ahmed, Pérez-Sánchez, Egea \& Candela, 1999).

\section{Pruebas de antagonismo in vitro}

En el Cuadro 3 se reportan los mecanismos de acción de cada uno de los hongos evaluados. Con base en las pruebas de antagonismo, se observó que todos los aislamientos de Trichoderma invadieron las colonias de $P$. cinnamomi por el mecanismo de competencia, y en algunos casos debido al micoparasitismo ocasionaron lisis. En todas las confrontaciones, los aislamientos de Trichoderma fueron capaces de reducir el crecimiento y desarrollo del patógeno (Figura 1). La colonización del área compitiendo por espacios y nutrientes es una manera de ejercer biocontrol, al reducir o detener completamente el desarrollo del micelio del patógeno (Dennis \& Webster, 1971), lo que permite visualizar que Trichoderma es un buen candidato en el control biológico de $P$. cinnamomi. Las pruebas in vitro mostraron que existe diferencia significativa $(P=0.05)$ en el crecimiento de $P$. cinnamomi en presencia de hongos antagonistas (Figura 2).

Barnet y Binder (1973) mencionan propiedades de antagonismo de los géneros Gliocladium, Cephalosporium y Trichoderma como micoparásitos de hongos fitopatógenos. Por su parte, Papavizas (1985) también reportó que Trichoderma y Gliocladium constituyen dos agentes de biocontrol, cuya habilidad es actuar como micoparásitos de hongos fitopatógenos del suelo. El género Trichoderma se encuentra distribuido ampliamente en casi todos los suelos, especialmente en aquellos que contienen materia orgánica (Kubicek \& Harman, 1998). En general, Trichoderma spp. aumenta la actividad antifúngica al presentar una velocidad mayor de crecimiento y, como consecuencia, el tamaño de la colonia de $P$. cinnamomi se reduce. Estos resultados concuerdan con los de Soler et al. (1998), quienes observaron un efecto claro de antagonismo de Trichoderma contra $P$. cinnamomi y Rosellinia necatrix, en cultivos duales in vitro. Al respecto, Dennis y Webster (1971) mencionan que el sobrecrecimiento es un carácter ventajoso para la colonización en la competencia por espacio y nutrientes. Los resultados del presente estudio son comparables cinnamomi colonies by the competition mechanism, and in some cases due to mycoparasitism they caused lysis. In all comparisons, Trichoderma isolates were able to reduce the pathogen's growth and development (Figure 1). The colonization of the area competing for space and nutrients is a way of exerting biocontrol, by reducing or completely stopping the pathogen's mycelium development (Dennis \& Webster 1971), which allows deducing that Trichoderma is a good candidate for $P$. cinnamomi biological control. In vitro tests showed that significant difference $(P=0.05)$ exists in the $P$. cinnamomi growth in the presence of antagonistic fungi (Figure 2).

Barnet and Binder (1973) reported antagonism properties of the genera Gliocladium, Cephalosporium and Trichoderma as mycoparasites of phytopathogenic fungi. Meanwhile, Papavizas (1985) also reported that Trichoderma and Gliocladium are two biocontrol agents, whose ability is to act as mycoparasites of phytopathogenic soil fungi. Trichoderma genus is widely distributed in almost all soils, especially those containing organic matter (Kubicek \& Harman, 1998). In general, Trichoderma spp. increases antifungal activity by showing a higher growth speed and, consequently, the $P$. cinnamomi colony size is reduced. These results are in accordance with those of Soler et al. (1998), who observed a clear antagonism effect of Trichoderma against $P$. cinnamomi and Rosellinia necatrix, in dual cultures in vitro. In this regard, Dennis and Webster (1971) mentioned that the overgrowth is advantageous for colonization in the space and nutrients competition. The results of this study are also comparable with those obtained by Smith, Wilcox and Harman (1990) on the Trichoderma against $P$. cactorum activity in apple, where there was also a pathogen's growth reduction.

The Gliocladium and Paecilomyces fungi (Figure 1) inhibited pathogen's growth by antibiosis, without being in contact with the $P$. cinnamomi hyphae, since there was a free growth zone between these fungi. This shows that there is a secondary metabolites production that may be affecting pathogen's growth through antibiotics or enzymes production, so that these isolates are another potential alternative for $P$. cinnamomi biocontrol.

\section{Antagonists species' morphological and molecular identification}

\section{Trichoderma}

Trichoderma genus showed septate mycelium, simple, thin, hyaline; conidiophore hyaline; amerosporas hyaline conidia mass produced apically in green coloration on simple phialides (Figure 3 ). Table 4 describes the Trichoderma species found in El Arrayanal (TC-1, TC-2, TC-4, TC-6) and Tecoanapa (TG-1, TG-3, TG-4, TG-6).

The genus Cordyceps bassiana (morphologically identified as Gliocladium) (GC), Paecilomyces (PC) and Cladosporium (CC) were identified at El Arrayanal; while 

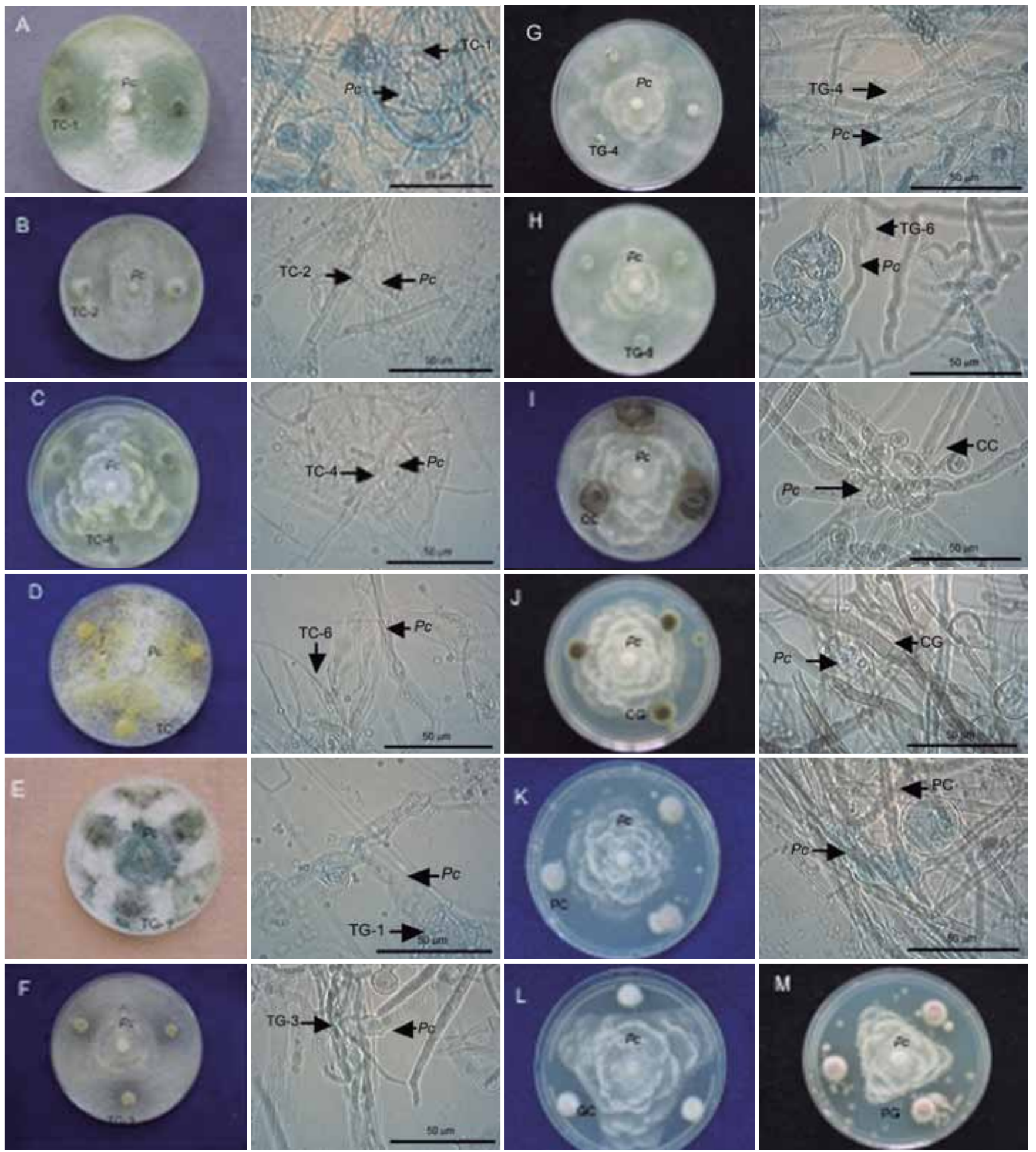

FIGURA 1. Antagonismo de los aislamientos evaluados sobre Phytophthora cinnamomi (Pc). Trichoderma (A [TC-1], B [TC-2], C [TC-4], D [TC-6], E [TG-1], F [TG-2], G [TG-4], H [TG-6]) actúa por micoparasitismo provocando micelio deshidratado e hifas entrelazadas; los antagonistas sobrecrecen al patógeno y cubren el $100 \%$ de la caja. Cladosporium (I [CC] y J [CG]) y Paecilomyces (K [PC]) actúan también por micoparasitismo presentando micelio deshidratado e hifas entrelazadas. Con Gliocladium (L [GC]) y Paecilomyces (M [PG]) el crecimiento se detiene por inhibición.

FIGURE 1. Antagonism of the isolates tested on Phytophthora cinnamomi (Pc). Trichoderma (A [TC-1], B [TC-2], C [TC-4], D [TC-6], E [TG-1], F [TG-2], G [TG-4], H [TG-6]) acts by mycoparasitism causing dehydrated mycelium and interlaced hyphae; antagonists overgrow the pathogen and cover $100 \%$ of the box. Cladosporium (I [CC] and J [CG]) and Paecilomyces (K [PC]) also act by mycoparasitism causing dried mycelium and interlaced hyphae. As for Gliocladium (L [GC]) and Paecilomyces (M [PG]), they stop the growth by inhibition. 

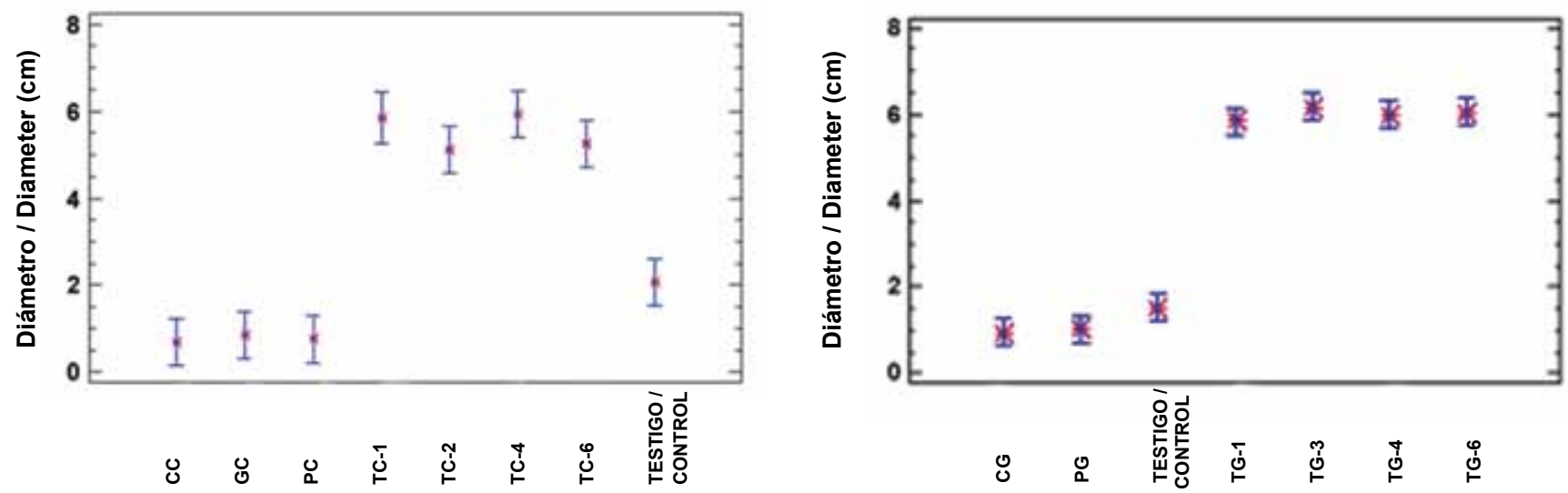

FIGURA 2. Crecimiento de hongos antagonistas de Colima (a) y Guerrero (b). Los aislamientos de Trichoderma (TC-1, TC-2, TC-4, TC-6, TG-1, TG-3, TG-4, TG-6), Gliocladium (GC), Cladosporium (CC-CG) y Paecilomyces (PC-PG) mostraron capacidad inhibidora contra Phytophthora cinnamomi.

FIGURE 2. Fungi antagonists' growth from Colima (a) and Guerrero (b). Trichoderma isolates (TC-1, TC-2, TC-4, TC-6, TG-1, TG-3, TG-4, TG-6), Gliocladium (GC), Cladosporium (CC-CG) and Paecilomyces (PC-PG) showed inhibitory capacity against Phytophthora cinnamomi.

con los obtenidos por Smith, Wilcox y Harman (1990) en la actividad de Trichoderma contra $P$. cactorum en manzano, donde también se observó una reducción en el crecimiento del patógeno.

Los hongos Gliocladium y Paecilomyces (Figura 1) inhibieron el crecimiento del patógeno por antibiosis, sin tener contacto con las hifas de $P$. cinnamomi, ya que se observó una zona libre de crecimiento entre dichos hongos. Esto demuestra que existe producción de metabolitos secundarios que pueden estar afectando el crecimiento del patógeno a través de la producción de antibióticos o enzimas, por lo que estos aislamientos son otra alternativa potencial para el biocontrol de $P$. cinnamomi.

\section{Identificación morfológica y molecular de las especies antagonistas}

\section{Trichoderma}

El género Trichoderma presentó micelio septado, simple, delgado, hialino; conidióforo hialino; conidios hialinos amerosporas producidos apicalmente en masa de coloración verde sobre fiálides simples (Figura 3). En el Cuadro 4 se describen las especies encontradas de Trichoderma en El Arrayanal (TC-1, TC-2, TC-4, TC-6) y Tecoanapa (TG-1, TG-3, TG-4, TG-6).

En el Arrayanal se identificaron a nivel de género Cordyceps bassiana (identificado morfológicamente como Gliocladium) (GC), Paecilomyces (PC) y Cladosporium (CC); mientras que en Tecoanapa también se identificó a Paecilomyces (PG) y Cladosporium (CG).

\section{Cordyceps bassiana (GC)}

Es un microorganismo saprofito y común en los suelos. En PDA presentó micelio blanquecino algodonoso; conidióforos hialinos formando una brocha com- in Tecoanapa also Paecilomyces (PG) and Cladosporium (CG) were identified.

\section{Cordyceps bassiana (GC)}

This is a saprophyte microorganism very common in soils. In PDA showed white cottony mycelium; hyaline conidiophores forming a compact brush; hyaline conidia or brightly colored mass, unicellular produced apically (Figure 3).

\section{Paecilomyces (PC and PG)}

This fungus is characterized for showing conidiophores with divergent branches in PDA; chains of conidia (phialospore), unicellular, ovoid, hyaline (Barnett \& Hunter, 1998) (Figure 3).

\section{Cladosporium (CC and CG)}

In PDA it showed dark conidia formed by one or two cells of variable size, ovoid, cylindrical or some lemony shape, arranged in simple or branched chain (Barnett \& Hunter, 1998) (Figure 3).

\section{Molecular characterization}

The PCR products with primers ITS4 and ITS5 were approximately weighing between 500 to $550 \mathrm{bp}$ (base pairs), which allowed the amplification of the bands observed in Figure 4. The sequencing results of each isolate were compared with the reported sequences in the gene bank (NCBI). Sequences in this work, considered a 90 to $100 \%$ alignment. The species registered in GenBank getting their access number, are reported in Table 5.

\section{CONCLUSIONS}

All isolated soil fungi associated with oak trees are reported for the first time in Mexico. Also in this work, the identification of species Trichoderma hipocrealixil, T. stri- 

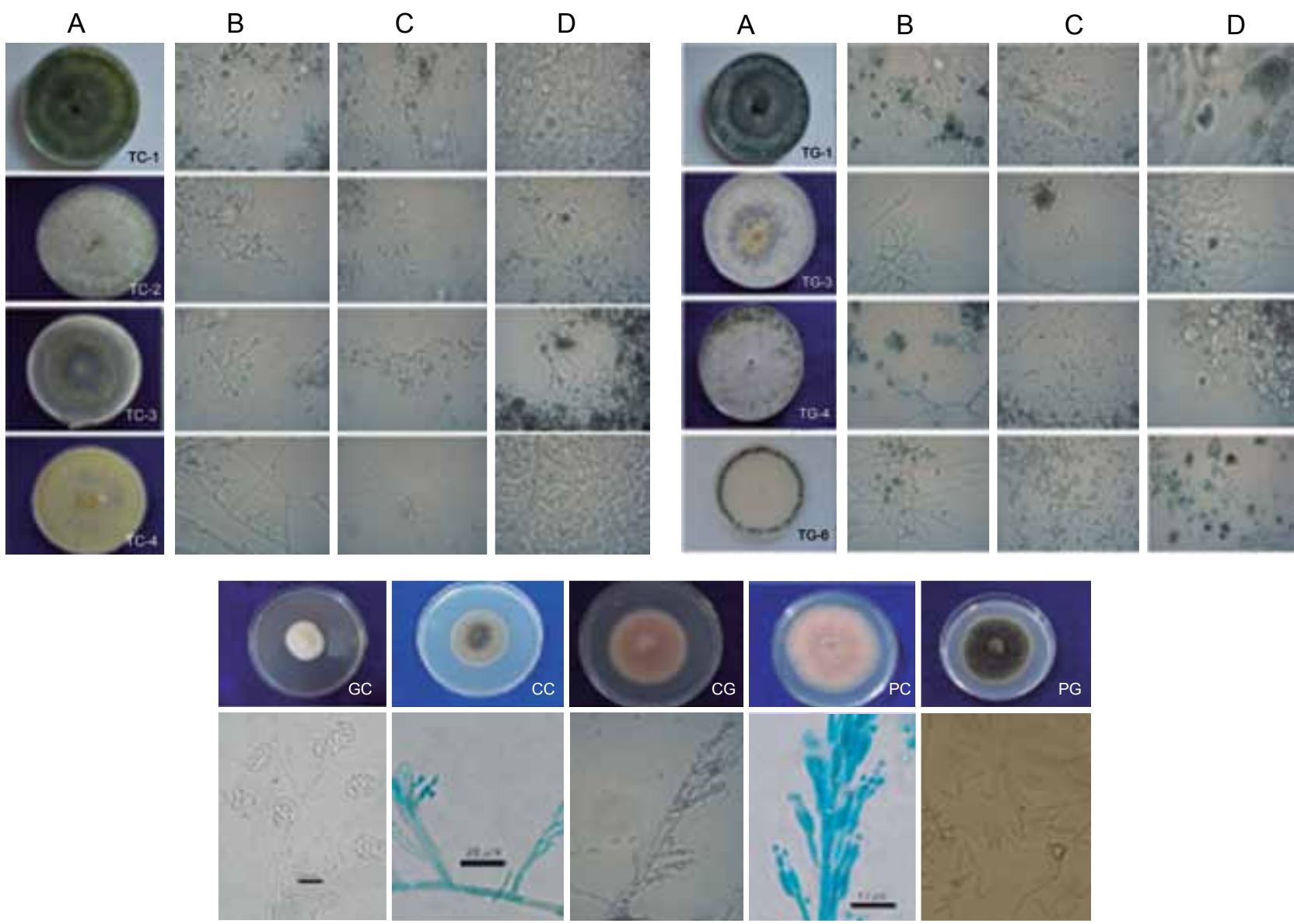

FIGURA 3. 3A) Colonias de Trichoderma (TC-1, TC-2, TC-4, TC-6, TG-1, TG-3, TG-4 y TG-6) de seis días de crecimiento en medio PDA a temperatura ambiente. 3B) Fiálides. 3C) Conidios. 3D) Clamidosporas (100X). 3E) Colonias de Gliocladium (GC), Cladosporium (CC, CG) y Paecilomyces (PC, PG) de ocho días de crecimiento en PDA a temperatura ambiente. 3F) Conidióforos y conidios (100X).

FIGURE 3. 3A) Trichoderma colonies (TC-1, TC-2, TC-4, TC-6, TG-1, TG-3, TG and TG-4 and TG-6) of six days of growth on PDA media at room temperature. 3B) Phialides. 3C) Conidia. 3D) Chlamydospores (100X). 3E) Gliocladium colonies (GC), Cladosporium (CC, CG) and Paecilomyces (PC, PG) of eight days of growth on PDA at room temperature. 3F) Conidiophores and conidia (100X).

CUADRO 4. Mediciones comparativas para Trichoderma spp. de El Arrayanal, Colima y Tecoanapa, Guerrero.

\begin{tabular}{lcccc}
\hline Especie & Clave & $\begin{array}{c}\text { Conidios } \\
(\boldsymbol{\mu m})\end{array}$ & Fiálides $(\boldsymbol{\mu m})$ & ${\text { Diámetro de la colonia }(\mathbf{c m})^{*}}^{*}$ \\
\hline Trichoderma longibrachiatum & TC-1 & $3.1-3.5$ & $6.3-10.5 \times 2.1-3.1$ & 1.5 \\
Trichoderma citrinoviride & TC-2 & $2.3-3.4$ & $3.3-6.5 \times 2.3-3.0$ & 1.5 \\
Trichoderma hamatum & TC-4 & $3.0-2.8$ & $3.3-5.6 \times 2.8-3.5$ & 1.25 \\
Trichoderma atroviride & TC-6 & $2.3-2.6$ & $\begin{array}{c}\text { Largas y delgadas de tres } \\
\text { a cuatro vértices }\end{array}$ \\
Trichoderma hipocrealixil & TG-1 & $2.1-2.9$ & $\begin{array}{c}\text { Ocasionalmente en pares, } \\
\text { verticiladas }\end{array}$ \\
Trichoderma atroviride & TG-3 & $2.7-2.6$ & $\begin{array}{c}\text { Tres o cuatro vértices } \\
\text { largas y delgadas }\end{array}$ \\
Trichoderma tringosum & TG-4 & $3.2-2.5$ & $\begin{array}{c}3.0-5.5 \times 2.9-3.5 \\
\text { Largas y solitarias }\end{array}$ \\
Trichoderma spirale & TG-6 & $2.4-3.2$ & 1.25 \\
\hline
\end{tabular}

*Incubación por 5 días a $21^{\circ} \mathrm{C}$ en medio de cultivo Papa Dextrosa Agar (PDA) 
TABLE 4. Comparative measurements for Trichoderma spp. from El Arrayanal (Colima) and Tecoanapa (Guerrero).

\begin{tabular}{|c|c|c|c|c|}
\hline Species & Key & $\begin{array}{c}\text { Conidia } \\
(\mu \mathrm{m})\end{array}$ & Phialides $(\mu \mathrm{m})$ & Colony diameter(cm)* \\
\hline Trichoderma longibrachiatum & $\mathrm{TC}-1$ & $3.1-3.5$ & $6.3-10.5 \times 2.1-3.1$ & 1.5 \\
\hline Trichoderma citrinoviride & TC-2 & 2.3-3.4 & $3.3-6.5 \times 2.3-3.0$ & 1.5 \\
\hline Trichoderma hamatum & $\mathrm{TC}-4$ & $3.0-2.8$ & $3.3-5.6 \times 2.8-3.5$ & 1.25 \\
\hline Trichoderma atroviride & TC-6 & $2.3-2.6$ & $\begin{array}{l}\text { Long and thin with three to } \\
\text { four vertices }\end{array}$ & 1.8 \\
\hline Trichoderma hipocrealixil & TG-1 & $2.1-2.9$ & $\begin{array}{l}\text { Ocasionally in pairs, ver- } \\
\text { ticillate }\end{array}$ & 1.25 \\
\hline Trichoderma atroviride & TG-3 & $2.7-2.6$ & $\begin{array}{l}\text { Three to four vertices, } \\
\text { long and thin }\end{array}$ & 1.3 \\
\hline Trichoderma tringosum & TG-4 & $3.2-2.5$ & $3.0-5.5 \times 2.9-3.5$ & 1.2 \\
\hline Trichoderma spirale & TG-6 & $2.4-3.2$ & Long and solitary & 2.0 \\
\hline
\end{tabular}

* Incubation during 5 days at $21^{\circ} \mathrm{C}$ in Potato Dextrose Agar (PDA) culture media

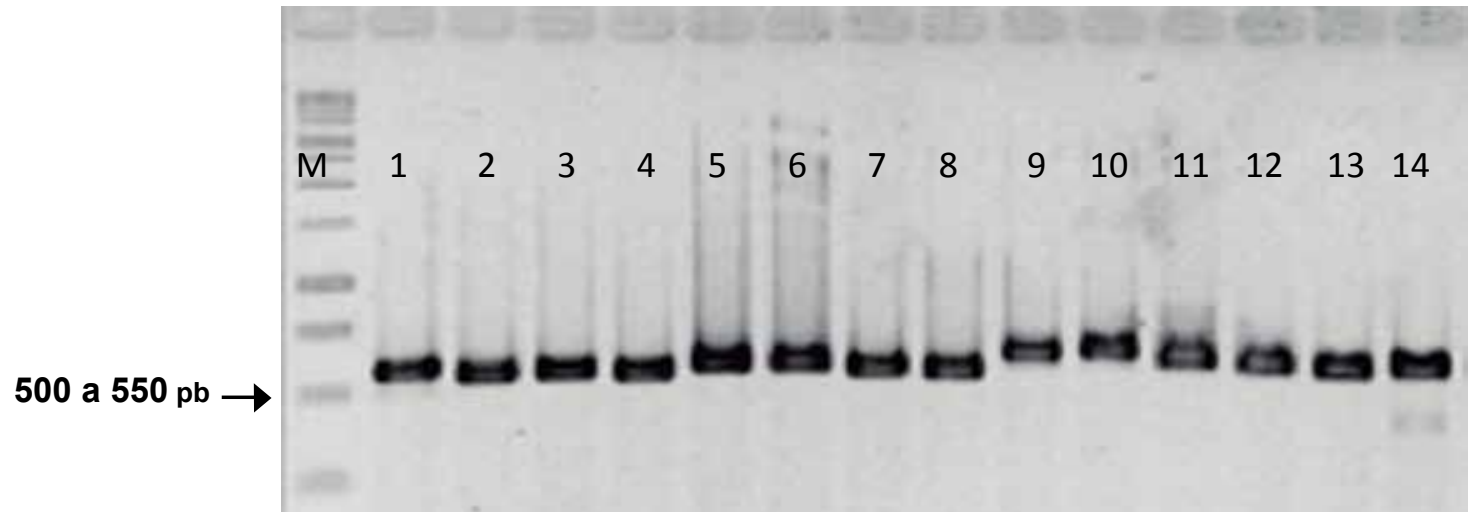

FIGURA 4. Electroforesis en gel de agarosa al $1 \%$ del producto amplificado por PCR con los iniciadores ITS4 e ITS5. M: Marcador molecular de $1 \mathrm{~Kb}$. Trichoderma (1 = TG-1, 2 = TG-3, 3 = TG-4, 4 = TG-6, 8 = TC-1, 9 = TC-2, 10 = TC-4, $11=$ TC-6), Gliocladium (7 = GC) Cladosporium (13 = CC, $5=\mathrm{CG})$, Paecilomyces $(12=\mathrm{CP}, 6=\mathrm{PG})$ y $P$. cinnamomi $(14=\mathrm{PC})$.

FIGURE 4. Gel electrophoresis in $1 \%$ agarose of the PCR amplified product with ITS4 and ITS5 primers. M: $1 \mathrm{~Kb}$ molecular marker. Trichoderma (1= TG-1, 2 =TG-3, 3= TG-4, 4= TG-6, 8 = TC-1, 9 = TC-2, 10= TC-4, 11 = TC-6), Gliocladium (7 = GC), Cladosporium (13 = CC, $5=$ CG), Paecilomyces (12 = CP, $6=$ PG) and $P$. cinnamomi $(14=\mathrm{PC})$.

pacta; conidios hialinos o brillantemente coloreados en masa, unicelulares, producidos apicalmente (Figura 3).

\section{Paecilomyces (PC y PG)}

En PDA este hongo se caracteriza por presentar conidióforos con ramas divergentes; conidios (fialosporas) en cadena, unicelulares, de forma ovoide, hialinos (Barnett \& Hunter, 1998) (Figura 3).

\section{Cladosporium (CC y CG)}

En PDA presentó conidios de color oscuro formados por una o dos células de tamaño variable, ovoides o cilíndricos y algunos de forma alimonada, arreglados en cadena simple o ramificadas (Barnett \& Hunter, 1998) (Figura 3).

\section{Caracterización molecular}

Los productos de PCR con los primers ITS4 e ITS5 tuvieron un peso aproximado de 500 a 550 pb (pares de bases), lo que permitió la amplificación de las bandas gosum, T. spirale, T. longibrachiatum, T. citrinoviride, T. atroviride, Cordyceps bassiana and Cladosporium tenuissimun was done. Trichoderma, C. bassiana and Paecilomyces isolates are the best for biocontrol because they reduced the $P$. cinnamomi development in all in vitro tests showing outstanding mechanisms of space competition and mycoparasitism. As a result, these native isolates are good biological control agents.

End of English Version

que se observan en la Figura 4. Los resultados de la secuenciación de cada aislamiento fueron comparados con las secuencias reportadas en el banco de genes (NCBI). En las secuencias de este trabajo se consideró un alineamiento de 90 al $100 \%$. En el Cuadro 5 se reportan las especies que fueron registradas en el Banco de Genes obteniendo su número de acceso. 
CUADRO 5. Identificación morfológica y molecular de aislamientos antagonistas a Phytophthora cinnamomi.

\begin{tabular}{|c|c|c|c|c|c|}
\hline $\begin{array}{l}\text { Identificación } \\
\text { morfológica }\end{array}$ & $\begin{array}{c}\text { Clave de } \\
\text { aislamiento }\end{array}$ & $\begin{array}{l}\text { Número de } \\
\text { nucleótidos }\end{array}$ & Especie alineada & $\begin{array}{c}\text { Similaridad } \\
(\%)\end{array}$ & $\begin{array}{c}\text { Número de acceso } \\
\text { NCBI }\end{array}$ \\
\hline $\begin{array}{l}\text { Trichoderma } \\
\text { hipocrealixil }\end{array}$ & TG-1 & 608 & T. hipocrealixil & 100 & FJ361039 \\
\hline T. atroviride & TG-3 & - & Trichoderma sp. & 90 & - \\
\hline T. strigosum & TG-4 & - & T. strigosum & 90 & - \\
\hline T. spirale & TG-6 & - & T. spirale & 95.7 & - \\
\hline $\begin{array}{l}\text { Cladosporium tenuis- } \\
\text { simun }\end{array}$ & CG & 545 & $\begin{array}{l}\text { Cladosporium } \\
\text { tenuissimun }\end{array}$ & 99.8 & FJ361040 \\
\hline Paecilomyces & $P G$ & - & - & & - \\
\hline P. cinnamomi & Ha1 & 909 & P. cinnamomi & 100 & FJ361041 \\
\hline T. longibrachiatum & TC-1 & 632 & T. longibrachiatum & 99 & FJ361035 \\
\hline T. citrinoviride & TC-2 & 624 & T. citrinoviride & 99.6 & FJ361036 \\
\hline T. hamatum & TC-4 & - & - & & - \\
\hline T. atroviride & TC-6 & - & T. atroviride & 95.4 & - \\
\hline Paecilomyces sp. & PC & - & - & & - \\
\hline Cladosporium & $\mathrm{CC}$ & - & Cladosporium & 94.7 & - \\
\hline Gliocladium & GC & 560 & $\begin{array}{l}\text { Cordyceps } \\
\text { bassiana }\end{array}$ & 99.2 & FJ361037 \\
\hline P. cinnamomi & $P_{C}$ & 913 & P. cinnamomi & 100 & FJ361038 \\
\hline
\end{tabular}

TABLE 5. Morphological and molecular identification of isolates antagonists to Phytophthora cinnamomi

\begin{tabular}{|c|c|c|c|c|c|}
\hline $\begin{array}{c}\text { Morphological } \\
\text { identification }\end{array}$ & Isolation key & $\begin{array}{c}\text { Nucleotide } \\
\text { number }\end{array}$ & Aligned species & Similarity (\%) & Access number NCBI \\
\hline $\begin{array}{l}\text { Trichoderma } \\
\text { hipocrealixil }\end{array}$ & TG-1 & 608 & T. hipocrealixil & 100 & FJ361039 \\
\hline T. atroviride & TG-3 & - & Trichoderma sp. & 90 & - \\
\hline T. strigosum & TG-4 & - & T. strigosum & 90 & - \\
\hline T. spirale & TG-6 & - & T. spirale & 95.7 & - \\
\hline $\begin{array}{l}\text { Cladosporium tenuis- } \\
\text { simun }\end{array}$ & CG & 545 & $\begin{array}{l}\text { Cladosporium } \\
\text { tenuissimun }\end{array}$ & 99.8 & FJ361040 \\
\hline Paecilomyces & $P G$ & - & - & & - \\
\hline P. cinnamomi & Ha1 & 909 & P. cinnamomi & 100 & FJ361041 \\
\hline T. Iongibrachiatum & TC-1 & 632 & T. longibrachiatum & 99 & FJ361035 \\
\hline T. citrinoviride & TC-2 & 624 & T. citrinoviride & 99.6 & FJ361036 \\
\hline T. hamatum & TC-4 & - & - & & - \\
\hline T. atroviride & TC-6 & - & T. atroviride & 95.4 & - \\
\hline Paecilomyces sp. & $\mathrm{PC}$ & - & - & & - \\
\hline Cladosporium & $\mathrm{CC}$ & - & Cladosporium & 94.7 & - \\
\hline Gliocladium & GC & 560 & $\begin{array}{c}\text { Cordyceps } \\
\text { bassiana }\end{array}$ & 99.2 & FJ361037 \\
\hline P. cinnamomi & $P c$ & 913 & P. cinnamomi & 100 & FJ361038 \\
\hline
\end{tabular}




\section{CONCLUSIONES}

Todos los hongos aislados del suelo asociados con el arbolado de encino se reportan por vez primera en México. Se identificaron las especies de Trichoderma hipocrealixil, T. strigosum, T. spirale, T. longibrachiatum, T. citrinoviride, T. atroviride, Cordyceps bassiana y Cladosporium tenuissimun. Los aislamientos de Trichoderma, C. bassiana y Paecilomyces son los que ejercieron mejor biocontrol al reducir el desarrollo de $P$. cinnamomi en las pruebas in vitro mostrando mecanismos sobresalientes de competencia por espacio y micoparasitismo. Debido a ello, estos aislamientos nativos son buenos controladores biológicos.

\section{REFERENCIAS}

Agrios, N. G. (2001). Fitopatología. México, D. F: Editorial Limusa.

Ahmed, S. A., Perez-Sánchez, C., Egea, C., \& Candela, M. E. (1999). Evaluation of Trichoderma harzianum for controlling root caused by Phytophthora capsici in pepper plants. Plant Pathology, 48, 58-65. doi: 10.1046/j.1365-3059.1999.00317.x

Ahrens, U., \& Seemuller, E. (1992). Detection of DNA of plant pathogenic mycoplasma like organisms polymerase chain reaction that amplifies a sequence of the 16S RNA gene. Phytopathology, 82, 828-832. Obtenido de http://www.apsnet.org/publications/phytopathology/backissues/Documents/1992Articles/ Phyto82n08_828.pdf

Alexander, M. (1980). Introducción a la microbiología del suelo. México: AGT Editor.

Álvarez, S. J. D., \& Ferrera-Cerrato, R. (1994). Los microorganismos del suelo en la estructura y función de los agroecosistemas. México: Colegio de Postgraduados.

Alvarado-Rosales, D., Saavedra-Romero, L. de L., Almaraz-Sánchez, A., Tlapal-Bolaños, B., Trejo-Ramírez, O., Davidson, J. M., Quiroz-Reygadas, D. (2007). Agentes asociados y su papel en la declinación y muerte de encinos (Quercus, Fagaceae) en el centro-oeste de México. Polibotánica, 23, 1-21. Obtenido de http://www.herbario.encb.ipn.mx/pb/pdf/pb23/1Encino.pdf

Alvarado-Rosales, D., Saavedra-Romero, L. de L., Almaraz-Sánchez, A. (2008). Primer reporte de Phytophthora cinnamomi Rands. asociado al encino (Quercus sp.) en Tecoanapa, Guerrero, México. Agrociencia, 42, 565-572. Obtenido de http://www.colpos. $\mathrm{mx} /$ agrocien/Bimestral/2008/jul-ago/art-8.pdf

Barnett, H. L., \& Hunter, B. B. (1998). Illustrated genera of imperfect fungi. St. Paul, Minnesota, USA: The American Phytopathological Society.

Barnett, H. L., \& Binder, F. L. (1973). The fungal host-parasite relationship. Annual Review of Phytopathology, 11, 273-292. doi: 10.1146/annurev.py.11.090173.001421

Burges, A., \& Raw, F. (1971). Biología del suelo. Barcelona, España: Ediciones Omega.

Campbell, C. K., Johnson, E. M., Philpo, C. M. T., \& Warnock, D. W. (1996). Identification of Pathogenic Fungi. London, UK: Public Health Laboratory Service.

Cibrián-Tovar, D., Alvarado, R. D., \& García, D. S. (2007). Enfermedades forestales en México. México: Universidad Autónoma Chapingo.
Dennis, L., \& Webster, J. (1971). Antagonistic properties of speciesgroups of Trichoderma III. Hyphal interaction.Transactions of the British Mycologycal Society, 57, 363-369. doi: 10.1016/ S0007-1536(71)80050-5

Domsch, H. K., Gams, W., \& Anderson, T. H. (1980). Compendium of Soil Fungi. London, UK: Academic Press.

Erwin, D. C., \& Ribeiro, O. K. (1996). Phytophthora diseases worldwide. USA: APS-Press.

Estudio de Reordenamiento Territorial de Xalpatláhuac. (2004). GEA. AC/PROCYMAF II.

Kubatova, A. (1996). Neglected Penicillium spp. associated with declining trees. In R. A. Samson, \& J. L. Pitt (Eds.), Integration of modern taxonomic methods for Penicillium and Aspergillus classification (pp. 299-307). Singapore: Taylor \& Francis, Inc.

Kubicek, C. P., \& Harman, G. E. (1998). Trichoderma \& Gliocladium. Vol. 1 Basic biology, taxonomy and genetics. London, UK: Taylor \& Francis.

Lumley, T. C., Gignac L. D., \& Currah, R. S. (2001). Microfungus communities of white spruce and trembling aspen logs at different decay stages in disturbed and undisturbed sites in the boreal mixed wood region of Alberta. Canadian Journal of Botany, 79, 76-92. Obtenido de http://www.nrcresearchpress.com/doi/ abs/10.1139/b00-135

Martínez, V. O., Valenzuela, F. E., \& Godoy, B. R. (2005). Hongos aislados desde suelos de bosque de Araucaria-Nothofagus después de un incendio en el parque nacional Tolhuaca. Boletín Micologíco, 20, 35-39. Obtenido de http://micologia.uv.cl/images/ stories/article/17/1.5araucaria_notofagus.pdf

Moreno, G. S., Martínez, R. A., Encino, F. J., Moreno, G. F., Rauna, T. C., Michel, M. M., \& Figura, M. S. (2001). Ejido Lic. Fernando Moreno Peña. Proceso de Afectación. Declinación del Encino. México: Ecofor. Servicios Forestales de Impacto Ambiental.

Papavizas, G. C. (1985). Trichoderma and Gliocladium: Biology, ecology and potential for biocontrol. Annual Review of Phytopathology, 23, 23-54. doi: 10.1146/annurev.py.23.090185.000323

Sharma, G. D. (1981). Effect of fire on soil microorganism in a meghalaya pine forest. Folia Microbiologica (Praha), 26, 321-327. doi: 10.1007/BF02927260

Smith, V. L., Wilcox, W. F., \& Harman, G. E. (1990). Potential for biological control of Phytophthora root and crown rots of apple by Trichoderma and Gliocladium spp. Phytopathology, 80, 880-885. Obtenido de http://www.apsnet.org/publications/phytopathology/backissues/Documents/1990Articles/Phyto80n09_880.PDF

Soler, A., Grondona, I., Montero, M., López H., Llobell, A., \& Monte, E. (1998). Selección de cepas de Trichoderma antagonistas de Phytophthora cinnamomi y Rosellinia necatrix para su aplicación en cultivos de aguacate. Salamanca, España: IX Congreso de la Sociedad Española de Fitopatología.

Steiner, G. W., \& Watson, R. D. (1965). Use for Surfactants in the soil dilution and plate count method. Phytopathology, 55, 728-730.

Waterhouse, G. M. (1963). Key to the species of Phytophthora de Bary. UK: Commonwealth Mycological Institute.

White, T. J., Bruns, T., Lee, S., \& Taylor, J. (1990). Amplification and direct sequencing of fungal ribosomal RNA genes for phylogenetics. In M. A. Innis, J. J. G. Sninsk, \& J. T. White (Eds.), PCR Protocols: A Guide to Methods and Applications (pp. 315-322). San Diego, USA. Academic Press. 